DOI $10.14746 / \mathrm{ssp} .2021 .2 .1$

\author{
Olga Puchnina
}

Lomonosov Moscow State University

ORCID ID: 0000-0001-7862-4903

\title{
Adequate Interpretation of Socio-Political Values as a Conceptual Issue in the XXI Century (From the Perspective of the Concepts Used by B. Constant and A. Tocqueville)
}

\begin{abstract}
The article analyzes the transformation of concepts like liberty, equality, and democracy depending on the political, historical, and socio-cultural context. The author proposes to trace the significant difference in understanding "universal" socio-political values by using the classical liberal theories of B. Constant and A. de Tocqueville compared to modern international political processes. The author uses comparative and historical analysis methods, and a cultural and axiological approach to studying the ideology and politics. The argument is that the ancient understanding of liberty was irrelevant for the society of the XIX century, just as B. Constant's classical understanding of liberty no longer meets the changing socio-political needs of people living in the XXI century. It does not consider a fundamentally new sphere of human activity like freedom and privacy in the digital world. Recognizing the value of democracy, the author observes that today, A. de Tocqueville's approach is more than adequate for understanding political processes. For example, the post-election information warfare in the United States in 2020 shows the relevance of the specific understanding of Tocqueville's democracy as a profound process of total equality spread. The main conclusion is that the political values familiar to modern discourse often are interpreted inadequately to reality since scientific understanding is rigid and lags behind the rapid development of information technologies, globalization, and virtualization.
\end{abstract}

Key words: democracy, liberty, values, transformation, politics

$\mathbf{T}$ The rapid development of technology, globalization, and digitalization has led the humanity of the twenty-first century to being united and cooperative more than ever before. However, against hopes and expectations, it has not solved the problems and contradictions of social development, as it often aggravated them even more.

The international market, the global economy, the need to unite for solvation of global problems, and the ease of crossing borders, territorial, 
linguistic, and cultural ones, have contributed to the spread and consolidation of an almost unified view of political culture, the goals and objectives of the socio-political development in the modern society. However, most political concepts claim to be universal, unique, and effective on a global scale. It is difficult to disagree that values such as liberty, justice, humanism, and democracy are fundamental for a modern person. These are the basic axiological coordinates of development and activity at the level of the state, international area, politics, and people's everyday lives.

However, in our opinion, there are several fundamental issues here. First, many modern researchers indicate that recognizing the universality of democratic values does not guarantee the growing socio-economic contradictions. On the one hand, the rejection of national, cultural, religious, and historical distinctiveness should have helped unite people with common ideas on increasing tolerance and reducing aggression, which resulted in nationalist and radical sentiments (Harrison, 2008, pp. 15-26). On the other hand, eliminating national and cultural features of the intellectual tradition has led to a significant semantic narrowing and impoverishment of concepts. For example, it has happened to the Russian understanding of liberty. As noted by researchers-philologists, before the XVIII century, in Russia, the central concept was "latitude" [vol'nost'], which was associated with privilege. However, later, the word liberty was "filled with new meanings, correlates with the emerging pan-European conceptualization of liberty as a universal right" (Varzin, 2011, p. 211).

Meanwhile, the dependence of real politics on the meaning of sociopolitical ideas adopted at the state and the ruling elite level is evident. It means that "it is important to evaluate the main socio-political concepts not only from a global perspective but also taking into account the national conditions of a particular country and their significance in the progressive development of society" (Tsaregorodtsev, Shirinyants, 2018, p. 64).

Secondly, even if we recognize such democratic values as liberty, equality, and justice as universal for all humanity, regardless of nationality, culture, and religion, it is evident that their interpretations strongly correlate with the historical context. Some researchers indicate that the "key concepts of the history of ideas do not have a priori supra-historical status but are 'indicators' and 'factors' of the cultural experience that they organize being themselves its outcomes" (Plotnikov, 2017, p. 49). It means "the issue of the historical and conceptual variability - to what extent we may discuss the history of the concept and whether there are other 
ways to constitute the unity of this process in addition to its attribution to a single dictionary word" (Plotnikov, 2017, p. 49).

We want to dwell on this aspect in more detail because, despite the seemingly unified axiological discourse of modern society, the explicit content of values meant in each particular case is different. It creates a paradox when, in a single global world, speaking, conditionally, in one language - that is, using identical words, the meaning may be different. Consequently, it becomes difficult to achieve mutual understanding.

Undoubtedly, this problem did not arise in the XXI century. Many thinkers of earlier periods have highlighted such a disparity in the content and form of widely used socio-political concepts. Of course, almost every era of social development insists on its uniqueness of circumstances, conditions, and personalities. Moreover, in this regard, the temptation to deny the past's intellectual heritage, relevance, and predictive functions great. Even though it is precious for understanding the specifics of past epochs, it hopelessly is outdated in the new realities of the twenty-first century. However, despite the share of justice of this position, classical socio-political works can deliver a lot to understand the essence of current transformational processes.

\section{"Liberty" eternal and unchangeable?}

The French philosopher, publicist, and politician Henri-Benjamin Constant de Rebecque (1767-1830) formulated the problem and negative socio-political consequences of the inadequate interpretation of values in the XIX century. As a representative of classical French liberalism and the author of the "textbook of liberty" (as it was called The Course of Constitutional Politics), Constant was also an active political figure in the most turbulent period of French history. He actively supported the Directory, drew up an Additional Act to the Constitution of Napoleon, received a seat in parliament after the restoration of royal power (Laboulaye, 1905). The main merit of Constant as a liberal theorist is not as much his original views as the generalization and systematization of the liberal ideas of that time (Callot, 1987). Constant's view on representative government and the protection of individual's rights and liberties remains relevant today. Furthermore, we still use Constant's classical definition of civil liberty, since it has become a modern practice.

Constant gave a lecture "The Liberty of Ancients Compared with that of Moderns" almost two hundred years ago in December 1819, which 
later became famous. The main merit of this short essay is that Constant clearly and logically, in broad strokes, outlined the essence of main issues inherent to the political and public life of the post-revolutionary French (in fact, pan-European) society. Namely, that, despite the scale of political transformations and their "liberty-loving" pathos, they did not bring actual freedom and relief to the situation of French society. Constant sees the reason in an outdated understanding of the value of "liberty." The French revolution followed the polis' state model of Ancient Greece in the name of liberty. At the same time, it was supposed to solve the problems and meet the needs of a radically changed modern French society.

According to Constant, the ancient people understood liberty primarily as political liberty, which meant the collective exercise of the supreme power, that is, the discussion of war and peace issues, the conclusion of alliances with foreigners, the voting of laws, the passing of decisions (Constant, 1993, p. 101). However, at the same time, ancient people allowed the individual's complete subordination to the community's authority. "Personal independence does not extend to opinions, nor occupations, much less to religion. To be able to choose one's faith, an opportunity which we regard as one of our most precious rights would have seemed in ancient times a crime and a sacrilege. In matters that seem to us the most insignificant, the authority of the social organism dominates the will of individuals and oppresses it" (Constant, 1993, p. 102).

According to the philosopher, there was a fundamental transformation of the content while preserving the very concept of "liberty." For the modern man, liberty consists precisely of personal freedom and relatively limited participation in public life.

With a fair amount of self-confidence, Constant explains the reason for this transformation and outlines the fundamental changes in the social and political structure of the human community from the VIII century $\mathrm{BC}$ to the end of the XVIII century. Accordingly, the main differences between modern and ancient societies are the changing size of states, the displacement of the past continuous wars by trade activities, and the disappearance of the slavery (Tavadova, 2016).

These three factors, in turn, have had a decisive impact on the social and political structure, and daily life of a person. A significant development of modern states has made the individual almost invisible and has led to the representative institutions' development. As the adult male population and power source, military activity has given way to commerce, which with much lower costs allows to achieve the same outcome 
and even more. However, according to Constant, trade takes up a lot of modern man's time and generally draws his attention mainly to personal interests instead of social participation. The abolition of slavery also significantly reduced the leisure opportunities inherent to a modern man.

Thus, according to Constant, the radical change in human existence conditions explains why it became impossible to follow the ancient ideal of liberty, which meant the continuous and active participation of the individual in collective political activity, already in the XIX century. Therefore, the all-attractive ideal of liberty borrowed from polis democracy times, placed on the French revolutionaries' banners, is useless (Karimov, 2012).

Constant concludes that the proper understanding of liberty is the peaceful use of personal independence, which includes the "classic" - for a person of the XXI century - freedom of speech, conscience, education, movement, property, choice of profession, and others. Civil liberties are becoming more critical for a modern person who has less and less time, opportunities, and most importantly, desire to engage in political activity (Todorov, 1997). By the way, Constant saw one of the dangers belonging to the mass society future.

With characteristic enthusiasm, the liberal philosopher advocated the development of representative government and citizen engagement in different social activities as a guarantor of personal independence and the stable and long-term existence of the state (Rosenblatt, 2009).

Constant has grasped the essence of the socio-political issue in the sphere of human life. Ideas and concepts that explain reality and set the future direction do not keep up with the actual development of society. Almost always, conventional and widespread ideas about what is necessary become archaic before they could reflect the real needs of society and persons' development accelerating each decade.

\section{Liberty in the twenty-first century}

Constant's works are essential today. Understanding individual liberty, the logic of socio-political processes, and the arguments favoring the spread of a representative government as the most relevant to the changed conditions of life seem almost truisms to us. They have firmly entered the consciousness and everyday practice of modern European people (Krasheninnikova, 2003).

However, it is difficult to argue that society made a leap in development in scale and significance no less than from the Ancient World to the 
Great French Revolution in the following two hundred years. Nevertheless, in the mass consciousness and socio-political rhetoric, the concept of liberty often is used precisely after Constant. Furthermore, despite the great history of the XX century's political philosophy, there is no single definition of liberty that would reflect all its essential features.

Political regimes in the era of globalization and mass development of Internet technologies are in entirely different conditions, creating new opportunities for direct political participation of an individual and a massive space for manipulation and restriction of political liberty.

The electronic culture of the XXI century defines entirely new conditions and forms of communication and self-determination in the modern world. Virtualization, free access to open information, the development of artificial intelligence, technocracy, no borders, and the dominance concerned the visual over the semantic phenomenon of mass consumption are already firmly established in our lives and change human existence. We can conclude that the man of the XXI century is a perfect new man: a "modern man is no longer just Homo Sapiens, but a largely virtualized 'biosocioelectronic' subject, which has activity both in the sphere of its bodily nature, social practice, and in a new capacity as an electronicvirtual subject, which has technological superpowers (overcoming spacetime boundaries and speeds) and which takes part in the global Internet community" (Baeva, 2013, p. 18).

However, at the level of legal norms and socio-political rhetoric, Constant's definition of liberty remains classical (Frolov, 2011, p. 60) and seems relevant.

Thus, recognized as the highest value and seemingly intuitive, liberty turns out to have entirely various meanings in different periods of history (Leroux, 2014). According to some modern scholars, the "uncertain categorical apparatus of liberal theory and fuzzy concept of liberalism is due, including conceptual and ideological flexibility of liberal theory, the desire of several liberals to implement universal and pluralistic approaches of ideas" (Gutorov, Shirinyants, 2020, p. 20).

\section{Democracy as the guiding star of humanity}

There are many examples of such an interpretation of "universal" human values irrelevant to the actual state of affairs. Another polysemantic concept, for example, is democracy. Of course, Plato's nega- 
tive interpretation of democracy as the most unstable and irregular government got reinterpretations. A positive assessment of democratic institutions and indirect representative government came into the light from the XVIII century. In the future, the democratic ideal of the social structure only gained strength and ideological sympathies (VidalNaquet, 2000; Canfora, 2006). Today, most civilized states are proud to declare themselves democratic. Even though the concept of democracy has a vibrant tradition, the main analytical tool for its features bases on the interpretation of democracy as a particular form of government - the people's power and the citizens' rights system that allows for effective political decision-making. However, this understanding of democracy is by no means the only one. Moreover, even the generally accepted definition of democracy as the public power gives excellent scope for specific content, depending on the goals and objectives set. For example, only in the Western European political literature of the XIX - first half of the XX centuries, we may trace the "birth of liberal, conservative, Marxist and social-democratic approaches to the interpretation of democracy" (Concepts..., 2006, p. 13).

It is appropriate to turn again to the history of the social and political thought of the XIX century, which gave brilliant examples of the original creative method, particularly to the works of the French philosopher and politician Alexis de Tocqueville (1805-1859). He offers an entirely different interpretation of the democracy concept, which was relevant in his time and which fits perfectly into the political development of America, Europe, and Russia in the XXI century.

Tocqueville was a member of the French aristocratic family. A real politician, at one time, even held the post of Minister of Foreign Affairs of France, the leader of the Conservative Party of order, is known in history primarily as the author of the work Democracy in America (1 volume - 1835, 2 volume - 1840) (Wolin, 2001).

France, which had experienced unprecedented revolutionary upheavals, where the republican form of government shifted with the restoration of the monarchy, nevertheless knew very little about true democracy as a form of government, and even less about the social and political structure of the New World - the United States of America. Tocqueville goes on an extended working trip to America and then, following his impressions, writes a historical-political paper in two volumes. He gives an original assessment to the order of things compared to his usual aristocratic world of the French monarchy. 
First of all, Tocqueville shrewdly established the relationship between mores, faith, and political institutions, while he understood faith as a psychology and a particular perception of the world. Furthermore, psychological relations, among all other relations as economic, legal, moral, in his opinion, are the most important from the socio-political perspective. Tocqueville focused primarily on the psychology of the community. $\mathrm{He}$ had been one of the first to assess the role of the crowd in history.

It led him to a fundamentally different understanding of democracy: this is not just a form of government but a global trend of social development that goes back to the Middle Ages. According to Tocqueville, a continuous democratic revolution has been taking place worldwide for a long time - the universal and irreversible spread and development of democracy (Manent, 1993; Boudon, 2005). In this process, he sees something fatalistic, independent of the people's will. In the spirit of the Enlightenment, Tocqueville deduces the reasons for this direction of social development from human nature, which was adequate to the desire for liberty and equality (Benoit, 2004).

In his opinion, the essence of the democratic revolution is the destruction of the aristocratic world and its gradual replacement by a democratic system. Tocqueville sees the spread of democracy as such a global process that he compares to the spread of Christianity in his time. In a democratic society, citizens are equal among themselves, just as the Christian religion once proclaimed equality before God. By another feature uniting Christianity and democracy, Tocqueville considers the clergy replenishing from different estates. However, when proclaiming the modern equality of citizens to be greater than it has ever been, Tocqueville "resolutely breaks with the classical tradition of political science, which naturally relies on the experience of the past, and above all, on the integral experience of ancient civilization in its completeness" (Coutant, 2008). Christian civilization in its straight-line development has finally overcome the classical legacy, and the cyclical evolutions of ancient societies can no longer serve as a basis for any predictions (Salmin, 2005, pp. 224-225). "A completely new society needs a new political science", writes Tocqueville, "but we do not think about that at all. Being in the middle of a fast-flowing river, we stubbornly direct our gaze to some remnants still visible on the shore, while the current carries us away and carries us into the abyss" (Tocqueville, 1992, p. 30).

Thus, Tocqueville's concept meant an entirely new approach to defining democracy. All previous political philosophers considered democracy 
primarily as a form of government, public self-government. On the other hand, Tocqueville saw something more in democracy. He saw an unprecedented historical event, the causes, and consequences of which are not confined solely to the sphere of government.

At the same time, studying the phenomenon of democracy, Tocqueville nowhere defines it as such. Interestingly, the most helpful description of Tocqueville's idea of democracy was delivered by J. St. Mill: "By democracy, Tocqueville means the equality of the estates, the absence of an aristocracy, whether it bases on political privileges or the superiority of personal importance and social power" (Mill, 1864, p. 198). Tocqueville believes that democracy is not as much a political system as a social one. In the spread of democracy, he sees the general trend of human development, of all progress - the desire for greater equality between people (Mill, 1994).

Already in the first half of the XIX century, it was evident for Tocqueville that democracy had been poorly connected with the direct form of political structure. He wrote about modern France that it had been going "maybe to despotism, maybe to the republic, but in any case to the democratic structure of society" (Tocqueville, 1992, p. 161), and this prospect awaits all humanity without exception. He wrote about this in the preface to his book Democracy in America: "The gradual establishment of equality is a divine inevitability. The following main features mark this process: it is global, long-term, and every day less and less dependent on people's will; all events, like all people, contribute to its development. Is it reasonable to believe that the efforts of one generation can suspend such a far-reaching social process? Does anyone think that by destroying the feudal system and defeating the kings, democracy will retreat before the bourgeoisie and the rich? Will it stop now that it has become so powerful and its opponents are so weak?" (Tocqueville, 1992, p. 24). The global "democratization" is thus irreversible and universal. However, it will lead to different consequences in different countries - in some to despotism, in others to freedom.

Speaking of the democratic revolution, Tocqueville also does not mean only the overthrow of political power literally. He assumes it to be a peaceful, social, and gradual process of expanding the rights and freedoms of citizens. However, its revolutionary nature means a radical change in social relations. The main contrast here is an aristocratic society with a rigid structure and hierarchy. Tocqueville believed that the aristocracy was falling, class inequalities were smoothing out, and classes were 
equalizing. This democratic tide is going on irresistibly, growing stronger and stronger, and having already overthrown the aristocracy and the king, it will not stop before the bourgeoisie. Moreover, if for the Anglo-Saxon world and America, Tocqueville predicted a peaceful transition to democracy through reforms. Nevertheless, according to his logic, a revolutionary path was more likely for Russia and continental Europe.

According to Tocqueville, it is clear that the "democratization" cannot be simultaneous because of restructuring the social system. That is a long stage in the history of every nation. Tocqueville wrote about France, "The year 1830 ended this first period of our revolutions, or rather our revolution, because we had, among the various revolutions, only one revolution, the beginning of which our grandfathers saw, and the end of which we, in all probability, will not see" (Tocqueville, 1893, p. 10).

However, for Tocqueville it is evident that political governance also changes through a democratic change in society. Nevertheless, the establishment of equality does not guarantee freedom by default. For Tocqueville, it is apparent that democratic equality can perfectly get along with despotism. Today, in the XXI century, one can ask whether the numerous "extraordinary" and "unique" events of the last hundred years are connected with the socio-political processes of the XVIII-XIX centuries much more closely than it seems at first glance.

It is noteworthy that based on his experience of observing democracy in the most developed form in America at that time, Tocqueville does not idealize it at all. He points out, like Montesquieu, that many reasons for the people's predisposition to democracy are found in its history, the peculiar climate, the location, the specific colonial structure, the national character, the habits and interests of society. So, the fact that America has "overtaken" the rest of the world in a democratic system does not mean that this option is a model and ideal for everyone else.

Although Tocqueville was a hereditary aristocrat and sympathized with society's monarchical and traditional political structure, his attitude to democracy was reasonable and sound. Remarking that the process of developing democracy is irreversible and parallel to the development of civilization, it is no longer possible to stop it, even with a strong desire. Tocqueville poetically compares democracy in the modern world to a river - we cannot turn it around, but we can choose to drown cities or water gardens and fields with it.

That is, democracy initially contains two equally possible potencies - the equality of citizens as a true democracy and the equality of citizens 
in a despotic state (Drescher, 1968). The main factor that manifests itself in the democratic social system is individualism, personal independence, resulting in isolation from almost all social groups and being lost in the crowd, becoming vulnerable to manipulation by the authorities (Rousselin, 2014). Tocqueville was one of the first to turn on its head the main argument of the democracy supporters - its apparent transparency. The thinker, on the other hand, "did not equate democracy with transparency. There is something opaque about the work of democracy, no matter how successful it may be, because the driving forces of its success never fully manifest themselves on the chaotic surface of democratic life. However, Tocqueville knew that the era of democracy would be built on faith" (Runciman, 2019, p. 35).

\section{Total or totalitarian equality of democracy?}

Today, Tocqueville's arguments of almost 200 years ago sound very relevant. The "democracy" concept has already become so firmly embedded in everyday socio-political discourse and has received such broad semantic connotations that its meaning has become highly blurred (Krasin, 2012). Modern authors point out such conceptual difficulties and explain it by the fact that "the democratic idea is alive, often self-renewing, open, and, as historical practice, including American, shows, internally contradictory" (Batalov, 2010, p. 39), but this does not solve the problem.

Almost all the self-proclaimed world democratic states are far from the original meaning of democracy as "the power of the people". The technology of manipulating public opinion and real-world political behavior have become almost commonplace. Individualism and the atomization of society, together with the rapid development of information technology, have made governing from above more than simple while maintaining citizens' appearance of direct participation in solving socio-political issues. It was precisely these consequences of the democratic equalization of citizens that Tocqueville feared, predicting the establishment of despotism against the background of a decline in the general intellectual level and the development of mass society.

Today democracy does not qualitatively characterize its political form, as it did two hundred years ago. However, it should be explicit in the logic of Tocqueville's reasoning as the increasing spread of equality in society. 
If, for Tocqueville, the spread of equality in society was evident at the level of all-classes citizens, genders, and races, but did not concern the inviolable level of power at that time, today we see the development of the same trend when the last hierarchical barriers fall. Social networks in our time have already turned from entertainment into an instrument of real political struggle, which has a tremendous mobilizing and organizing potential. Universal accessibility, a significant degree of free opinions and expressions, and the instantaneous transmission of information make possible feeling closeness between citizens and the authorities. They have become a surrogate for direct polis democracy when everyone has the right and opportunity to speak out.

We can remark the tendency to erase the boundaries between power and subjects. The relationship of authority and religious humility gradually gave way to rational respect and conscious reverence for the elected leaders, and today has transformed into a fraternal relationship of equal competitors. We can say that the idea of equality of all citizens, brought to its logical conclusion, in principle calls into question the very principle and the possibility of governance and power and certainly goes further and further from the original democratic ideal.

\section{The problem of adequate interpretation}

Therefore, through the example of two fundamental for the XXI century personal values, liberty and democracy, it is apparent how large is the gap between the language of political discourse and reality. Today, Constant's idea of the need for a radical rethinking of "traditional" and "classical" ideas about a person, society, values, and goals sounds appropriate. The conceptual apparatus of the ordinary level and the professional and scientific level do not keep up with the ever-accelerating changes in the essence of social processes. The same concepts, which history is alike with human civilization, are used today uncritically, by default, and old-fashioned. At the same time, the signified has long been irrelevant or has acquired fundamentally new semantic meanings.

The ever-accelerating pace of life, the development of science and technology, the exponential growth of informatization in various human activity spheres, globalization, and the virtualization of public space lead to the gap between the declared guidelines, values. Moreover, the real 
needs of modern man and society are increasingly expanding. The opportunities for adequate and timely understanding of them, on the contrary, are shrinking. Many authors consider such axiological transformations connected with the transition from the industrial to the postindustrial phase of social development. They point out that these "processes can create prerequisites for the emergence of a dangerous social conflict" (Partsvaniya, Khupenia, 2018, p. 279).

The XXI century society faces a considerable number of challenges to state stability, development, and the realization of citizens' rights and freedoms. Without canceling the achievements of past eras in the field of civil law, it seems that today the problematic accents are increasingly shifting toward the digital space, information security, and the confidentiality of personal data. In this area, the most rapid but not apparent at first glance, transformations occur today. Therefore, an adequate assessment and adaptation to the inevitably changing meanings of "eternal" values is a condition for preserving political systems' potential for development and stability. Therefore, it is possible to agree with the conclusion of the modern Dutch researcher F. Ankersmit. He concludes, "Without a philosophically developed understanding of the democratic state nature, we will never be able to solve the numerous and serious political problems that we will face in the next millennium" (Ankersmit, 2014, p. 35).

\section{Bibliography}

Ankersmit F. R. (2014), Aesthetic politics: political philosophy beyond fact and value, Publishing House of Higher School of Economics, Moscow.

Baeva L. V. (2013), Existential risks of the information age, "Information Society", vol. 3.

Batalov E. Ya. (2010), The problem of democracy in American Political Thought of the XX century, Progress-Tradition, Moscow.

Benoit J.-L. (2004), Understanding Tocqueville, Armand Colin, Paris.

Boudon R. (2005), Tocqueville today, Odile Jacob, Paris.

Callot E.-F. (1987), Liberal Thought in the nineteenth century through three moments of its formation: Benjamin Constant, Alexis de Tocqueville, Lucien A. PrévostParadol, Lyon.

Canfora L. (2006), Democracy: history of an ideology, Seuil, Paris.

Concepts and Definitions of Democracy: Anthology (2006), KomKniga, Moscow, URSS. 
Constant B. (1993), On the liberty of the ancients in its comparison with the liberty of modern people, "Polis (Political Studies)", vol. 2.

Constant B. (2000), Principles of politics suitable for all government, Classical French liberalism, Moscow.

Coutant A. (2008), Tocqueville and the democratic constitution, Mare et Martin, Paris.

Drescher S. (1968), Dilemmas of Democracy: Tocqueville and Modernization, University of Pittsburgh Press, Pittsburgh, PA.

Frolov E. D. (2011), Benjamin Constant and the Birth of the modern concept of the Ancient civil society, "Vestnik Sankt-Peterburgskogouniversiteta. Series 2", vol. 3 .

Gutorov V. A., Shirinyants A. A. (2020), Liberal tradition and modern anti-liberalism, "Bulletin of the YankaKupala Grodno State University. Series 1. History and Archeology. Philosophy. Political Science", vol. 12 (3).

Harrison L. E. (2008), The Central Liberal Truth: how politics can change culture and save it, New Publishing House: Liberal Mission Foundation, Moscow.

Karimov A. V. (2012), Fundamental concepts of social freedom of the XIX century, "Socio-economic phenomena and processes", vol. 9.

Krasheninnikova Yu. A. (2003), Lessons of classical French liberalism for modern liberal theory, "The Political Science", vol. 4.

Krasin Yu. A. (2012), On his deathbed or at the origins of reincarnation? What is happening with democracy, "Bulletin of the RSUH. Series: Political Science. History. International relations”, vol. 19 (99).

Laboulaye E. (1905), Political ideas of Benjamin Constant, Russian Thought, Moscow.

Leroux R., Hart D. M. (2014), The golden age of French liberalism, Ellipses, Paris.

Manent P. (1993), Tocqueville and the nature of democracy, Fayard, Paris.

Mill J. St. (1994), Essays on Tocqueville and American society, Vrin, Paris.

Mill J. St. (1864-1865), Reasonings and researches political, philosophical and historical: In 3 ch., V. Kovalevsky, St. Petersburg.

Partsvaniya V. R., Khupeniya N. R. (2018), Transformation of values in the process of formation of postindustrial society, "Liberal Arts in Russia", vol. 7, no. 4.

Plotnikov N. S. (2017), Notions of Liberty: Universalism and Cultural Particularity, "Ethical Thought", vol. 17 (1).

Rosenblatt H. (2009), Eclipses and Revivals: Constant's Reception in France and America (1830-2007), The Cambridge Companion to Constant, ed. H. Rosenblatt, University Press, Cambridge.

Rousselin P. (2014), Democracies in danger: how the world of tomorrow will be, Paris.

Runciman D. (2019), The confidence trap: history of the crisis of democracy from the First World War to the present day, Publishing House of Higher School of Economics, Moscow. 
Salmin A. M. (2005), The ideological heritage of A. Tocqueville and the modern political tradition of the West, "Journal of Political Philosophy and Sociology of Politics' Politiya. Analysis. The chronicle. Forecast", vol. 3.

Tavadova A. V. (2016), Between John Stuart Mill and Alexis de Tocqueville: two concepts of freedom, "Bulletin of the Moscow University. Series 18. Sociology and Political Science", vol. 2.

Tocqueville A. de (1893), Memoirs, Typo-lithography by V. Richter, Moscow.

Tocqueville A. de. (1992), Democracy in America, Progress, Moscow.

Todorov T. (1997), Benjamin Constant: the democratic passion, Hachette literatures, Paris.

Tsaregorodtsev S. S., Shirinyants A. A. (2018), In Search of Meaning: Ideas as a Factor of politics, "Bulletin of the Russian Nation", vol. 1 (59).

Varzin A. V. (2011), "Freedom" in vocabularies of the 19-th-beginning of the 20-th centuries: reflection of senses transformation under the influence of liberal ideology, "Political linguistics", vol. 1 (35).

Vidal-Naquet P. (2000), Greeks, historians, democracy: the big gap, Paris.

Wolin S. (2001), Tocqueville Between Two Worlds, Princeton University Press, Princeton, NJ.

\section{Adekwatna interpretacja wartości społeczno-politycznych jako problem pojęciowy w XXI w. (na przykładzie analizy pojęć B. Constant i A. Tocqueville)}

\section{Streszczenie}

Artykuł prezentuje analizę znaczącej transformacji wartości wolności, równości i demokracji w zależności od kontekstu politycznego, historycznego i społeczno-kulturowego. Autorka rekonstruuje różnice interpretacji „uniwersalnych” wartości społeczno-politycznych przez klasycznych teoretyków liberalizmu - B. Constanta i A. de Tocqueville'a - w kontekście nowoczesnych międzynarodowych procesów politycznych. Do badania wykorzystuje metody analizy porównawczej i historycznej, a także kulturowe i aksjologiczne podejście do badania sfery ideologicznej i politycznej. W efekcie pokazuje, że starożytne rozumienie wolności nie miało znaczenia dla społeczeństwa XIX wieku. Podobnie jest w przypadku wciąż żywotnej klasycznej interpretacji wolności B. Constanta, która jednak nie jest już adekwatna do potrzeb społeczno-politycznych osób żyjących w XXI wieku. Dzieje się tak, ponieważ całkowicie nie uwzględnia ona nowej sfery ludzkiej działalności - wolności i prywatności w cyfrowym świecie. Uznając wartość demokracji, autorka zwraca uwagę, że dziś bardziej adekwatne do zrozumienia procesów politycznych jest podejście A. de Tocqueville'a. Na przykład powyborcza wojna informacyjna w Stanach Zjednoczonych w 2020 roku pokazuje znaczenie specyficznego rozumienia demokracji Tocqueville'a jako głębokiego procesu całkowitego rozprzestrzeniania się równości. Stwierdza się, 
że wartości polityczne znane współczesnemu dyskursowi często są interpretowane nieadekwatnie do rzeczywistości, ponieważ zrozumienie naukowe jest relatywnie stałe i z tego powodu niedotrzymujące tempa szybkiemu rozwojowi technologii informacyjnych, globalizacji i wirtualizacji.

Słowa kluczowe: demokracja, wolność, wartości, transformacja, polityka 